\title{
Preliminary Phytochemical Screening and Antioxidant Activity of Ethanolic Leave Extract of Azadirachtaindica.
}

\author{
Ajetunmobi Asibiallau Oladipupo \\ Department of Science Laboratory Technology (Chemistry unit), School of Technology, LagosState Polytechnic, \\ Ikorodu, Lagos, Nigeria.
}

\begin{abstract}
The phytochemical constituent and some antioxidant indices of ethanolic leaf extract of Azadirachtaindica were evaluated. A. indica.was found to contain some secondary metabolites like alkaloids, phenolic compounds, terpenoids, flavonoids, steroids and reducing sugar.

The total phenolic content, reducing power and $\mathrm{H}_{2} \mathrm{O}_{2}$ scavenging activity are $3.04 \pm 0.03 \mathrm{mg} / \mathrm{g}$ garlic acid equivalent, $0.45 \pm 0.01$ and $10.15 \pm 1.14$ respectively. This shows that the plant has antioxidant activity, the phytochemical constituent explain why the plant has been used as antimicrobial agents for preventing and treating micro-organisms infections.

Keyword: Azadirachtaindica, phytochemical analysis and antioxidant activity.
\end{abstract}

\section{Introduction}

Medicinal plants are used by $80 \%$ of the world population as the only available medicines especially in developing countries (EL-Kamali\& EL-amir, 2010).

Herbal medicines already form the basis of therapeutic use in the developing countries, but of recent, there has been an increase in the use of herbal medicines in the developed world today (De and Ifeoma, 2002, ElMahmoodet al.,2010).

Practically, every part of the A. Indica (leaves, bark, fruit, flowers, oil and gum) has been reported to be associated with various remedial properties such as the treatment of general body pain after child delivery, pyorrhea, intestinal worms, antimicrobial effects, storage behaviour, in vitro antiviral activity and antibacterial agent (Biu et al., 2009: Taha et al., 2008).

The medicinal value of plants have assumed a more important dimension in the past few decades owing largely to the discovery that extracts from plants contain not only minerals and primary metabolites but also a diverse array of secondary metabolites with antioxidant potential. Antioxidant substances block the action of free radicals which have been implicated in the pathogenesis of many diseases including atherosclerosis, ischemic heart disease, cancer, Alzhelmer's disease, Parkinson's disease and in the aging process (Aruoma, 2003; Dasgupta and D'abrosca, 2007; Coruh et al., 2007).

Hence, scientists are now searching for naturally occurring antioxidants in plant sources for food or medicinal materials as alternative for synthetic antioxidants (D'Abrosca et al., 2007; Stanojevic et al., 2009).

Natural antioxidants endogenous to food of plant origin can scavenge reactive oxygen and nitrogen special (RONS); evidence suggests that these may be of great importance in preventing the onset of oxidative disease in the human body (Amarowicz et al, 2010).

Phenolic compounds contribute largely to the colour and sensory characteristics of fruits and vegetables. In addition, phenols participate in growth and reproduction processes, and provide protection against pathogens and predators. At the cellular level, it participate in cell protection against the harmful action of reactive oxygen species (ROS), mainly oxygen free radicals, produced in response to environmental stresses such as salinity, drought, high light intensity or mineral nutrient deficiency, because of the imbalance between the production and scavenging of ROS in chloroplasts. These cytotoxic activated oxygen species can seriously disrupt normal metabolism through oxidative damage to lipids, proteins and nucleic acids. Accordingly, plants containing high concentrations of antioxidants show considerable resistance to the oxidative damage caused by the ROS, as shown in the case of salt stressed plants (Meot-Duros\&Magne, 2009).

The present work was designed to investigate the phytochemical and the antioxidant potential of the leave extract of Azadirachtaindica.

\section{COLLECTION OF PLANT MATERIALS}

\section{Materials And Methods}

The leaves Azadirachtaindica of were obtained from Sabo Market in IkoroduLocal Governmemnt, Lagos State. The leave were identified and authenticated by a botanist in the Department of Botany, University of Lagos, Nigeria. 


\section{PREPARATION OF PLANT MATERIAL}

The leave of Azadirachtaindica were dried at room temperature for a period of one week and powdered with aid of a mechanical grinder (blender). ETHANOLIC EXTRACTION OF AZADIRACHTAINDICA

$100 \mathrm{~g}$ of the powdered leaves was weighed and soaked in a $1 \mathrm{~L}$ Pyrex beaker containing distilled water/ethanol $(80 \%)$ in ratio $2: 8$ respectively (i.e $200 \mathrm{ml} / 800 \mathrm{ml}$ ) for 72 hours (three days) under intermittent stirring. The solution was filtered after three days using Whatman paper and concentrated in an oven at reduced pressure $\left(40^{\circ} \mathrm{C}\right)$ and completely dried until a deep -brown aromatic residue was obtained. The residue was stored in a refrigerator at $-4^{\circ} \mathrm{C}$ under air tight condition to prevent moisture until use.

\section{PHYTOCHEMICAL SCREENING OF THE EXTRACT}

The powdered leaves were subjected to qualitative chemical tests using the methods of Sofowara (2008). The components analyzed for are saponins, cyanogin glycosides, steroid,

Anthraquinones, Tannins, Flavonoids, alkaloid and reducing sugars.

Tannins: $0.2 \mathrm{~g}$ of the plant materials was dissolved in $10 \mathrm{ml}$ of distilled water and then filtered. A $2 \mathrm{~mL}$ of filtrate was pipetted into a test tube after which $2 \mathrm{~mL}$ of $15 \% \mathrm{FeCl}_{3}$ was added.

Colour change was observed. Blue-black presence indicated the presence of Tannins.

Alkaloids: $0.2 \mathrm{~g}$ of the plant materials was extracted with $200 \mathrm{ml}$ of methanol for 20 minutes on a water bath and then filtered. To $2 \mathrm{~mL}$ of cold water extract in different tubes, was added 6 drops of alkaloid reagents (Meyer's reagent).

Brownish -red precipitate indicate the presence of alkaloid

Cyanogenic glycosides: $200 \mathrm{mg}$ of powdered plant material was placed in each of 3 different test tubes labelled $\mathrm{A}, \mathrm{B}$ and $\mathrm{C}$, respectively. The powder in test tubes $\mathrm{A}$ and $\mathrm{B}$ were moistened with $5 \mathrm{~mL}$ of water, while that in test tube $\mathrm{C}$ was left dry. 3 pieces of freshly prepared sodium picrate paper were inserted into the mouth of each tube and stoppered. Test tube B was placed in a water bath while test tube A and C were kept at room temperature. After 30 minutes the colour of the picrate papers in each of the test tube were observed and recorded.

\section{Cardiac glycosides:}

- Salkowski's test: $200 \mathrm{mg}$ of the extract was dissolved in $2 \mathrm{~mL}$ of chloroform. Concentrated tetraoxosulphate (VI) acid was carefully added to form a lower layer. A reddish-brown at the interface indicated the presence of a steroidal ring.

\section{Reducing sugars:}

- Fehling's test: ethanolic extract of the powdered material was obtained by boiling on water bath. To $2 \mathrm{~mL}$ of the extract, in the test tube was added, $1 \mathrm{~mL}$ each of Fehling's solutions A and B. The mixture was shaken and heated in a water bath for 10 minutes. The colour obtained was recorded.

\section{Saponins:}

- Frothing test: ethanolic extract was obtained by boiling on water both. The extract was transferred into a test tube and shaken vigorously then was left to stand 10 minutes and the result noted. Frothing persistence meant saponins were present.

Flavonoids:200 mg of the powdered sample was boiled in $10 \mathrm{~mL}$ of absolute ethanol for 10 minutes. The solution was allowed to cool and then filtered. To $2 \mathrm{~mL}$ of the filtrate was added concentrated hydrochloric acid and magnesium ribbon. Pink-tomato red colour indicated the presence of flavonoids.

\section{Anthraquinone derivatives:}

Bontrager's test: Chloroform extract of the powdered sample was obtained by boiling on the water bath. To $2 \mathrm{~mL}$ of this extract, $1 \mathrm{~mL}$ of dilute (10\%) ammonia was added and the mixture was shaken. Any colour change was recorded.

Evaluation of reducing power

The reducing power of A.indica was determined by the method of Yen et al 1995.

Evaluation of $\mathrm{H}_{2} \mathrm{O}_{2}$ scavenging activity

The $\mathrm{H}_{2} \mathrm{O}_{2}$ scavenging activity of A.indica and standard was assayed by the method of Zhaoet al 2006 .

Measurement of Total phenolic content

The total phenolic content was determined by Folin-ciocalteu colorimetric method with little modification. Each extract $10 \mathrm{mg}$ was dissolved in distilled water and different concentraction of gallic acid (0.0078- 1$)$ were 
prepared in water. Sample $(40 \mu \mathrm{l}), 1 \mathrm{M}$ Folin-ciocalteu reagent $(20 \mu \mathrm{l})$ and $20 \% \mathrm{Na}_{2} \mathrm{CO}_{3} 60 \mu \mathrm{l}$ were mixed. The mixtures were kept in the dark at room temperature. Absorbance was measured at $760 \mathrm{~nm}$ using a UV-visible spectrophotometer. Total phenol content was determined from the standard calibration curve.

III. Results

Table 1. The Phytochemical analysis of Azadirachtaindica

\begin{tabular}{|l|l|c|}
\hline \multicolumn{1}{|c|}{ Phytochemical analysis } & \multicolumn{1}{|c|}{ Qualitative test } & Methanolic extractA. indica \\
\hline Saponin & Foam test & - \\
\hline Tannins & with Ferric chloride & + \\
\hline Phenolic compounds & with lead acetate & + \\
\hline Alkaloid & with Mayer's test and Dragendoff's & + \\
\hline Flavonoids & test & ++ \\
\hline Anthraquinones & with NaOH, with $\mathrm{Mg} / \mathrm{HCl}$ & +++ \\
\hline Terpenoids & Bontrager's test & ++ \\
\hline Cardiac glycosides & Thionyl chloride test & - \\
\hline Steroids & Legal test & ++ \\
\hline Reducing sugars & Liebermann Burchard test & ++ \\
\hline Non-reducing sugars & Benedict's test & ++ \\
\hline
\end{tabular}

- Absent, + Lowly present, ++ Moderately present and +++ Highly present

The Phytochemical analysis of ethanolic extract of Azadirachtaindica shows the presence of secondary metabolite like alkaloids, phenolic compounds, terpenoids, flavonoids, steroids and reducing sugar.

Table 2.Determination of reducing power, total phenolic content and $\mathrm{H}_{2} \mathrm{O}_{2}$ scavenging activity of Azadirachtaindica.

rachtaindica.
\begin{tabular}{|l|l|}
\hline Test & Ethanolic extract of Azadirachtaindica \\
\hline Reducing power & $0.45 \pm 0.01$ \\
\hline $\mathrm{H}_{2} \mathrm{O}_{2}$ scavenging activity & $10.15 \pm 1.14$ \\
\hline Total phenolic content & $3.04 \pm 0.03 \mathrm{mg} / \mathrm{g}$ garlic acid equivalent \\
\hline & \\
\hline
\end{tabular}

\section{Discussion}

Medicinal plants constitute an effective source of both traditional and modern medicines, herbal medicine has been shown to have genuine utility and about $80 \%$ of rural population depends on it as primary health care. Over years, the World Health Organization advocated that countries should interact with traditional medicine with a view to identifying and exploiting aspects that provide safe and effective remedies for aliments of both microbial and non-microbial origins. The phytochemical screening of Azadirachtaindica extract indicated the presence of tannins, saponins, alkaloids, flavonoids, etc (Table 1). Several studies have linked the presence of these bioactive compounds (secondary metabolites) in plants to produce some biological activity in man and animals and it is responsible for their use as herbs. These active constituents can be used to search for bioactive lead compounds that could be used in the partial synthesis of more useful drugs (Ogbonnia et al., 2008; El-Mahmood et al., 2010). The presence of these secondary metabolites in plants, produce some biological activity in man and animals and it is responsible for their use as herbs. Nevertheless, these bioactive products from medicinal plants are presumed to be safe without any compromising health effect, and thus widely used as self medication (Vaghasiya). These compounds also serve to protect the plant against infection by microorganisms, predation by insects and herbivores, while some give plants their odours and or flavours and some are responsible for their pigments (El-Mahmoodet al,. 2008). Azadirachtaindica has a total phenolic content of $3.04 \pm 0.03 \mathrm{mg} / \mathrm{g}$ garlic acid and a reducing power of $0.45 \pm 0.01$. Both parameters indicate that the extract possess potent antioxidant activity.

$\mathrm{H}_{2} \mathrm{O}_{2}$ scavenging activity of A. Indica has a value of $10.15 \pm 1.14$ (Table 2) this value is high when compared to the control (garlic acid). This is an indication that the extract has the potential of scavenging free radicals.

\section{References}

[1]. De, N. and Ifeoma, E. (2002). Antimicrobial effects of components of the bank extracts of neem (Azadirachtaindica A. Juss). J. Technol, Dve., 8: 2328.

[2]. EL-MhamoodAMDoughari JH, Ladan N (2008). Antimicrobial screening some enteric pathogenic microorganisms, Afr. J. Pharm Pharmcol. 2(5).

[3]. Aruoma OI (2003). Methodological considerations for characterizing potential antioxidant actions of bioactive components in plant foods. $\quad$ Mutation Res. 523(524):9-20.

[4]. Dasgupta N, D B (2004). Antioxidant activity of Piper betle L. leaf extract in vitro. Food Chem. 88: 219-224. 
[5]. D'Abrosca B, Pacifico S, Cefarelli G, Mastellone C, Fiorentino A. Limoncella' apple, an Italian apple cultivar: Phenolic and flavoniod contents and antioxidant activity. Food Chemistry 2007; 104:1333-1337.

[6]. Amarowicz R, Estrella I, Hernandez T, Robredo S, Troszynska A, Kosin ska A, Pegg RB. Free raical-scavenging capacity, antioxidant activity, and phenolic composition of green lentil (Lens culinaris). Food Chemistry 2010, 121:705-711.

[7]. Meot-Duros L, Magne C. Antioxidant activity and phenol content of Crithmummaritimum L. Leaves. Plant Physiology and Biochemistry, 2009; 47; 37-41.

[8]. Aiyelaagbe O.O., Osamudiamen PM. Phytochemical screening of active compounds in Mangiferaindica Leaves from Ibadan, Oyo State. Plant Science Research 2009; 2(1):11-13.

[9]. Akula, C., Akula, A. and Drew, R. (2003). Somatic Embryogenesis in colonial neemAzadirachtaindica A. Juss. J. Microbial. Res. 3:162-166.

[10]. Loo Ay, Jain K, Darah I. Antioxidant and radical scavenging activities of the Pyroligneous acid from a mangrove plant, Rhizophoraappiculate. Food Chemistry 2007; 104: 300-307.

[11]. Yen, GC and Chen, HY (1995). Antioxidant activities of various tea extracts in relation to their antimutagenicity ,Journal of Agriculture and Food Chemistry, vol.43 no. 1, pp. 27-32.

[12]. Ahmad I, Mehmood J, Mohammad F(1998): Screening of some Indian medicinal plants for their antimicrobial properties. J Ethnopharmacol, 62:183-193.

[13]. Sofowora, E.A (1994).Medical Plant and Traditional Medicine in Africa. University of Ife Press, Nigeria. Pp 1-23.

[14]. Vaghasiya, Y.K.; Shukla, V.J.; Chanda, S.V (2011). Acute oral toxicity study of Pluchea argutaboissextract in mice. J. Pharmacol. Toxicol.6, 113-123.

[15]. Schmutterer H.(1995). The Neem Tree: Source of Unique Natural Products for Integrated Pest Management, Medicine, Industry and Other Purposes, VCH, Weinheim, Germany, 1-696.

[16]. Girish K. and Shankara B.S., (2008). Neem - A Green Treasure.Electronic Journal of Biology.,4(3), $102-111$.

[17]. Parotta J.A.,(2001). Healing plants of Peninsular India., New York, CABI Publishing, 495-96

[18]. Ross I.A. (2001). Medicinal plants of the world: Chemical constituents, Traditional and modern medicinal uses, Totowa, New Jersy, 2, 81-85.

[19]. Sharma P., Tomar L., Bachwani M., Bansal V., (2011).Review on Neem (Azadirechtaindica):Thousand Problem One Solution, Int.Res. J. of Pharmacy;2(12), 97-102.

[20]. DjenontinTindo S., Amusant N., Dangou J., Wotto D.V., Avlessi F., Dahouénon-Ahoussi E., Lozano P., Pioch D. and Sohounhloué K.C.D.,(2012).Screening of Repellent, Termiticidal and Preventive activities on Wood, of Azadirachtaindicaand Carapaprocera(Meliaceae) seeds oils, ISCA J. Biological Sci., 1(3), 25-29.

[21]. Mondal D. and Mondal T., A Review on efficacy of AzadirachtaindicaA. Juss based biopesticides: An Indian perspective, Res. J.Recent Sci.,1(3), 94-99 (2012)

[22]. Brototi B., and Kaplay R.D., Azadirachtaindica(Neem): It's Economic utility and chances for commercial planned plantation in Nanded District, Int. J. Pharma, 1(2), 100-104 (2011)

[23]. Chatterjee A. and Pakrashi S.C., The Treatise on Indian Medicinal Plants, New Delhi: National Institute of Science Communication (CSIR) 3 75-78 (2010)

[24]. Kabeeruddin H., Makhzanulmufradat., New Delhi: Aijaz publishing house 400-11 (2007) 